\title{
BCL11A Gene
}

National Cancer Institute

\section{Source}

National Cancer Institute. BCL11A Gene. NCI Thesaurus. Code C97394.

This gene is involved in both the modulation of cell shape and lymphopoiesis. 